\title{
Campaign Contribution Limits in California, Oregon \& Washington: What a Difference It Makes
}

\author{
Priscilla L. Southwell ${ }^{1}$ \\ ${ }^{1}$ Department of Political Science, University of Oregon, Eugene, USA \\ Correspondence: Priscilla L. Southwell, Department of Political Science, University of Oregon, Eugene, Eugene, \\ OR 97403, USA. Tel: 541-232-4205. E-mail: psouth@uoregon.edu
}

Received: November 16, 2016

doi:10.5539/jpl.v10n2p82
Accepted: January 26, 2017 Online Published: February 28, 2017

URL: https://doi.org/10.5539/jpl.v10n2p82

\begin{abstract}
This research examines the current restrictions on campaign contributions to nonfederal candidates in the states of Washington, Oregon, and California, as well as the legal challenges in the latter two states. The impact of unrestricted contributions in Oregon had the effect of larger campaign coffers, per registered voter, for state house, state senate, and gubernatorial races for the 2014 election, as well as a more prominent role for wealthy individual donors.
\end{abstract}

Keywords: campaign contribution limits, Service Employees International Union v. Fair Political Practices Comm. (1992), California Prolife Council Political Action Committee v. Scully (1998), VanNatta v. Keisling (1997)

\section{Introduction}

The three westernmost U.S. states (Washington, Oregon, and California) share a similar political culture, as evidenced by their voting records, turnout rates, and a penchant for political and electoral reform. These states were among the first to liberalize voter registration laws and no-excuse absentee voting, and Oregon was the first to adopt all-mail elections, in 1998. Oregon also begin automatic voter registration in 2016. Despite these similarities, Oregon is the lone standout with regard to establishing campaign contribution limits. Oregon is one of the six states in the country that allow unlimited contributions to its nonfederal candidates or ballot measure campaign committees (National Conference of State Legislatures. 2016.)

Before discussing this standout characteristic of the state of Oregon, Tables 1 and 2 below are a summary of the existing contribution limits in the states of Washington and California. Washington voters enacted contribution limits in 1992 by approving Initiative 134. The Public Disclosure Commission enforces these limits and has the authority to make inflationary adjustments at the beginning of even numbered years. Only the state legislature or the voters through the initiative process, can make other changes to contribution limits, such as expanding or eliminating them (State of Washington, Public Disclosure Commission. 2016).

California's process was much more prolonged and difficult than that of Washington's. California voters passed several ballot measures that would have imposed campaign contribution limits, but each of them encountered several court challenges. In 1988, voters simultaneously passed an initiative sponsored by members of the state legislature. It was a comprehensive campaign finance reform measure. These contribution limits, and one other provision of this initiative, were later invalidated by a federal court on the basis that the limits were applied on a fiscal year basis, which favored incumbents. (Service Employees International Union v. Fair Political Practices Comm. (9th Cir. 1992) 955 F.2d 1312.) (State of California, 2016. "The History of the Political Reform Act.")

In 1997, the voters passed another ballot measure, which again placed limits on campaign contributions to candidates, but also added voluntary spending limits and imposed other restrictions aimed at supporting the concept of contribution limits. Before the measure was fully implemented, the federal district court issued a preliminary injunction against its enforcement. (California Prolife Council Political Action Committee v. Scully (1998). The court's preliminary injunction was upheld on appeal, but the case was remanded for further proceedings by the trial court. Before the trial court could issue its ruling, the bulk of this measure was repealed by Proposition 34. In the summer of 2000, concerned with the continued uncertainty over the fate of previous ballot measure, the state legislature voted to place Proposition 34 on the November 2000 ballot. It passed with a 59.9\% 
approval vote. This measure limited the amount of contributions a person can directly contribute to a candidate, expanded financial disclosure requirements, and prohibited contributions from lobbyists.

Table 1. State of Washington, Current individual and PAC contribution limits

\begin{tabular}{ccc}
\hline Recipient & Individual Contribution Limit & PAC Contribution Limit \\
\hline State Party Committee (Exempt) & No Limit & No Limit \\
State Party Committee (Non-Exempt) & No Limit & $\$ 5,500$ per Calendar Year \\
State Executive Candidate & $\$ 2,000$ per Election & $\$ 2,000$ per Election \\
Legislative Candidate & $\$ 1,000$ per Election & $\$ 1,000$ per Election \\
PAC & No Limit & No Limit
\end{tabular}

Source: State of Washington, Public Disclosure Commission. 2016. Accessed on 10/31/2016 at https://www.pdc.wa.gov/learn/contribution-limits.

Table 2. State of California, Current individual and PAC contribution limits

\begin{tabular}{ccc}
\hline Recipient & Individual/PAC Limit & Small Contributor Committee* Limit \\
\hline PAC (candidate) & $\$ 7,000$ & -- \\
PAC or State Party (Non-candidate) & No Limit & -- \\
Gubernatorial Candidate & $\$ 28,200$ per Election & $\$ 28,200$ per Election \\
Other Statewide Executive Candidate & $\$ 7,000$ per Election & $\$ 14,100$ per Election \\
Legislative Candidate & $\$ 4,200$ per Election & $\$ 8,500$ per Election \\
State Political Party (candidate) & $\$ 35,200$ & -- \\
\hline
\end{tabular}

* Any committee that meets all of the following: 1) has been in existence for at least six months; 2) receives contributions from 100 or more persons; 3) no one person has contributed more than $\$ 200$ per calendar year; and 4) the committee makes contributions to five or more candidates.

Source: State of California. 2016. Fair Political Practices Commission.

\section{Oregon's Continued Struggle}

Numerous efforts have been made to establish contribution limits in this state, such as the passage of a ballot measure in 1994. This measure limited campaign contributions by individuals and political action committees (PACs) in legislative and statewide races. However, in VanNatta v. Keisling (1997), the court found that campaign contributions are a form of speech protected by the Oregon Constitution. In 2006, two additional campaign finance reform measures were put before the voters; however, the measure that would have allowed such reforms under the Oregon Constitution failed to pass. The second measure, involving specific reforms, passed, but the Attorney General and the Secretary of State linked the two measures, and so the actual reforms were not enacted. This decision was upheld by the Oregon Supreme Court, who ruled this measure would be held in "abeyance," pending an appropriate constitutional amendment or judicial decision (Hazell v. Brown (2012).

In 2015, at the urging of Governor Kate Brown, formerly Secretary of State, two bills were introduced in the Oregon State Senate that would have continued the push for campaign finance reform, but each of them died in committee (The Oregonian, 2015).

\section{Previous Research}

So we consider three western states - two which have struggled to impose campaign limits, and one who seamlessly introduced them in 1972. Does it make a difference? Previous research has arrived at mixed results. Gross et al. (2002) examined the effectsof several different components of reform:contribution limits, public financing, and spending limits.They found that spending limits reduced candidate spending and had an indirect and negative effect on electoral competition. The negative effects of spending limits, however, were heavily contingent on the level of these contribution limits. They concluded that whether campaign finance reform enhances or inhibits electoral competition depends on the combination of spending limits, contribution limits, 
and public financing within a given state.

Stratmann and Aparicio-Castillo (2006) analyzed elections from 1980- 2001 to determine whether vote shares were affected by changes in state campaign contribution limits. They found that contribution limits narrowed the margin of victory of the winning candidate. However, they also found that such limits led to closer elections for future incumbents, but had less effect on the margin of victory of incumbents who predated the campaign finance legislation. They also found evidence that contribution limits increased the number of candidates in the race.

Eom and Gross (2007) analyzed contribution limits as a possible mechanism to lessen the influence of 'special interests' and to encourage greater citizen participation. They tested the argument that contribution limits 'democratize' the system of contributions by forcing candidates to rely on a larger number of small contributions. Their analysis of the number of contributors, the total amount of contributions, and the average amount given by contributors, suggest that contribution limits do have such a democratization effect.

Flavin (2015) addresses the argument that regulating the financing of campaigns attenuates the role of money in politics and promotes more egalitarian policy outcomes. Using data on state spending priorities from 1977 to 2008 , he found that states with stricter campaign finance laws devoted a larger proportion of their annual budget to public welfare spending in general and to cash assistance programs in particular. However, he found that there was no relationship between the strictness of campaign finance laws and spending decisions for non-redistributive policy areas. He also found that stricter campaign finance laws altered the incentives for candidates to respond to wealthy constituents by lessening the proportion of contributions that originated from business interests. He concluded that laws that regulate the financing of political campaigns can play an important role in promoting the interests of disadvantaged citizens and enhancing political equality.

\section{Data Analysis}

We now turn to our analysis of these three states. The results show that a great deal of money is flowing into the coffers of Oregon candidates, even given its relatively small population of slightly over 3 million. Table 3 shows that average contribution per voter in 2014 was higher in Oregon for state house, state senate, and gubernatorial races than either Washington or California. This figure represents the total $\$$ amount of contributions made to house, senate, and gubernatorial candidates, as three distinct sets of contributions, divided by the total number of statewide registered voters. The figure is higher for the state house in all states, because there are obviously a greater number of house/assembly seats for all three states, and therefore total contributions to candidates. These figure suggests that campaign contributions, and, therefore, expenditures remain relatively high in Oregon.

Table 3. A comparison of total campaign contributions per registered voter in state house/assembly, state senate, and gubernatorial races in Oregon, Washington \& California 2014 (\# of candidates)

\begin{tabular}{cccc}
\hline & State House & State Senate & Governor \\
\hline \multirow{2}{*}{ Oregon } & $\$ 11.88$ & $\$ 6.37$ & $\$ 5.24$ \\
& $(149)$ & $(35)$ & $(12)$ \\
Washington & $\$ 6.34$ & $\$ 4.49$ & No Race \\
& $(213)$ & $(56)$ & \\
California & $\$ 10.69$ & $\$ 4.43$ & $\$ 3.71$ \\
& $(246)$ & $(76)$ & $(26)$ \\
\hline
\end{tabular}

Source: National Institute on Money in State Politics. 2016.

We now turn to the analysis of the largest group and individual contributors in each state. The list of largest contributors in 2014 from Oregon, including to federal candidates and those committees in support or opposition to certain ballot measures, is shown in Table 4. This list includes the expected Democratic and Republican state campaign committees, as well as one union, several professional associations, and one corporation. 
Table 4. Top 15 non-individual contributors in Oregon 2014

\begin{tabular}{lr}
\hline \multicolumn{1}{c}{ Donor } & Total Contributions \\
\hline Oregon House Democratic Campaign Committee & $\$ 1,800,095$ \\
Oregon Democratic Party & $\$ 1,329,757$ \\
Oregon Public Employees Local 503 & $\$ 1,012,173$ \\
Promote Oregon Leadership* & $\$ 791,169$ \\
Oregon Senate Republican Leadership Fund & $\$ 773,431$ \\
Oregon Education Association & $\$ 604,990$ \\
Oregon Health Care Association & $\$ 565,233$ \\
Oregon Senate Democratic Campaign Committee & $\$ 534,404$ \\
Nike & $\$ 422,788$ \\
Oregon Nurses Association & $\$ 407,260$ \\
Associated Oregon Industries & $\$ 406,112$ \\
Coalition for a Healthy Oregon & $\$ 400,613$ \\
Oregon Trial Lawyers Association & $\$ 397,961$ \\
Oregon League of Conservation Voters & $\$ 372,027$ \\
ACTBLUE** & $\$ 342,376$ \\
\hline Gave only to Republican candidates &
\end{tabular}

Source: National Institute on Money in State Politics. 2016.

The largest individual contributor in Oregon in 2014 was Phil Knight, the founder and CEO of Nike Corporation. He donated $\$ 270,000$, primarily to the incumbent governor, John Kitzhaber. This contribution of $\$ 250,000$, just three weeks before the 2014 general election, became a subject of much controversy. Phil Knight had previously given primarily to Republican candidates, including John Kitzhaber's opponent in the 2010 gubernatorial election. Later, Governor Kitzhaber had called the legislature into a special session in December 2012 in order to consider a special tax break for Nike (Gunderson, 2014). The Governor also relaxed his initial concerns about using state funds to support a 2021 track event in Eugene, Oregon - a project supported by Phil Knight (Hubbard, 2016). The unsuccessful candidate for governor, Dennis Richardson, also received large contributions from several individuals - \$150,000 from Robert Freres, owner of Freres Lumber Company and \$122,000 from James Young, a retired CEO of Entek Manufacturing. The crucial point is that the level of these contributions to the gubernatorial candidates in Oregon would not have been possible under either Washington's or California's contribution limits.

\section{California: Top Contributors in 2014}

As shown in the Table 5 below, the dominant source of campaign contributions was the Democratic party, followed by the Republican party and numerous unions and professional associations. The top individual donors in California in 2014 were primarily candidates who ran for office that year. The top individual donor was Republican Neel Kashkari, the unsuccessful gubernatorial candidate, who donated over \$3 million to his own campaign. The largest donor, who was not a candidate, was Charles T. Munger, Jr., an experimental physicist at the Stanford Linear Accelerator Center and the son of billionaire Charles Munger-vice chairman of Berkshire Hathaway. He gave $\$ 410,750$ in $2014, \$ 54,400$ of this amount to Neel Kashkari, noted above. The real contrast between California and Oregon is that an individual such as Munger was able to give much less money to his preferred gubernatorial candidate than was the case in Oregon - all because of the California contribution limits, as described in Table 3 above. 
Table 5. Top 15 non-individual contributors in California 2014

\begin{tabular}{lr}
\hline \multicolumn{1}{c}{ Donor } & Total Contributions \\
\hline California Democratic Party & $\$ 14,830,310$ \\
California Republican Party & $\$ 6,017,722$ \\
San Luis Obispo Co. Republican Central Committee & $\$ 1,934,616$ \\
California Assn. of Realtors & $\$ 1,643,336$ \\
AT\&T & $\$ 1,248,010$ \\
California State Council of Laborers & $\$ 1,234,240$ \\
California Teachers Assn. & $\$ 1,147,583$ \\
California State Council of Service Employees & $\$ 1,116,475$ \\
Pechanga Band of Luiseno Mission Indians & $\$ 1,011,309$ \\
California State Assn. of Electrical Workers & $\$ 974,000$ \\
California School Employees Assn. & $\$ 909,025$ \\
State Building \& Construction Trades Council & $\$ 905,250$ \\
California Professional Fire Fighters Assn. & $\$ 883,455$ \\
Pacific Gas and Electric & $\$ 871,396$ \\
Professional Engineers in California Government & $\$ 792,060$ \\
California Faculty Association & $\$ 772,918$ \\
\hline
\end{tabular}

Source: National Institute on Money in State Politics. 2016.

\section{Washington: Top Contributors in 2014}

As shown in Table 6, the list of top contributors reveals a pattern that is similar to that of Oregon and California, but with a more prominent role for both party's organizations. Because Washington did not have a gubernatorial race in 2014, its individual-level contributions were relatively low, and, similar to California, the largest such donations came from individuals to their own campaigns.

Table 6. Top 15 non-individual contributors in Washington 2014

\begin{tabular}{|c|c|}
\hline Donor & Total Contributions \\
\hline Washington State Democratic Party & $\$ 909,956$ \\
\hline House Democratic Campaign Comm. Of Washington & $\$ 782,125$ \\
\hline Washington State Republican Party & $\$ 695,288$ \\
\hline House Rep. Organizational Comm. of Washington & $\$ 567,550$ \\
\hline Senate Democratic Campaign Comm. of Washington & $\$ 467,534$ \\
\hline Senate Republican Campaign Comm. of Washington & $\$ 388,027$ \\
\hline Northwest Credit Union Assn. & $\$ 190,500$ \\
\hline Boeing Co. & $\$ 186,550$ \\
\hline Premera Blue Cross & $\$ 184,100$ \\
\hline Washington State Dental Assn. & $\$ 179,820$ \\
\hline Washington State Auto Dealers Assn. & $\$ 170,750$ \\
\hline Delta Dental & $\$ 159,700$ \\
\hline BNSF Railway & $\$ 153,850$ \\
\hline Washington State Assn. for Justice & $\$ 142,550$ \\
\hline Weyerhauser & $\$ 141,550$ \\
\hline
\end{tabular}

Source: National Institute on Money in State Politics. 2016. 


\section{Summary and Conclusions}

These preliminary findings suggest that the absence of campaign contribution limits in Oregon results in more and larger contributions flowing into the campaign coffers of state house, state senate, and gubernatorial candidates in that state. In the case of the governor's race, Oregon's candidates received far more than any individual donor could contribute in California, despite its much smaller electorate. We can assume that this unrestricted giving in Oregon had the effect of making all such races more expensive in general, and perhaps discouraging potential candidates who could not attract such contributions. For this reason, the absence of contribution limits has caught the attention of watchdog organizations such as Common Cause, and seems to defy Oregon's other more innovative and progressive election laws (Common Cause, 2015).

\section{References}

Eom, K., \& Gross, D. (2007). Democratization effects of campaign contribution limits in gubernatorial elections. Party Politics, 13, 695-720. http:dx.doi.org/10.1177/1354068807081817

Flavin, P. (2015). Campaign finance laws, policy outcomes, and political equality in the American States. Political Research Quarterly, 68, 77-88. http:dx.doi.org/10.1177/1065912914554041

Gross, D. A., Goidel, R. K., \& Shields, T. G. (2002). State campaign finance regulations and electoral competition. American Politics Research, 30, 143-165. http:dx.doi.org/10.1177/1532673X02030002002

Gunderson, L. (2014). Phil Knight donates \$250,000 to John Kitzhaber campaign. The Oregonian, September 24. Retrieved February 11, 2016, from http://www.oregonlive.com/politics/index.ssf/2014/09/phil_knight_donates_250000_to.html

Hubbard, S. (2016). Cash trail leads to track subsidy. The Register-Guard, January 5, 2016, A1 \& A5.

National Institute on Money in State Politics. (2016). Election overview. Retrieved January 11, 2016, from http://www.followthemoney.org/election-overview?s=CA\&y=2014

State of California. (2016). Fair Political Practices Commission. State contribution limits and voluntary expenditure ceilings. $\quad$ Retrieved October 31, 2016, from http://www.fppc.ca.gov/learn/campaign-rules/state-contribution-limits.html

State of California. (2016). Fair Political Practices Commission. History of the political reform act. Retrieved October 31, 2016, from http://www.fppc.ca.gov/about-fppc/about-the-political-reform-act.html

State of Washington. (2016). Public Disclosure Commission. 2016. Retrieved October 31, 2016, from https://www.pdc.wa.gov/learn/contribution-limits

Stratmann, T., \& Aparicio-Castillo, F. (2006). Competition policy for elections: Do campaign contribution limits matter? Public Choice, 127, 177-206. http://dx.doi.org/10.2139/ssrn.274470

\section{Copyrights}

Copyright for this article is retained by the author(s), with first publication rights granted to the journal.

This is an open-access article distributed under the terms and conditions of the Creative Commons Attribution license (http://creativecommons.org/licenses/by/4.0/). 